\title{
Monetary Policy between Mexico, United States of America, and Canada
}

DOI: $10.46932 / \mathrm{sfjdv} 3 \mathrm{n} 1-010$

Received in: Dec 30st, 2021

Accepted in: Jan 1th, 2022

\section{Dr. Alberto Merced Castro Valencia}

Dr. Alberto Merced Castro Valencia profesor e investigador adscrito al departamento de gestion empresarial

Instituto tecnologico Jose Mario Molina Pasquel y Henriquez

E-mail: Alberto.castro@ zapopan.tecmm.edu.mx

\begin{abstract}
This article examines the evolution of the monetary policy of the economies that make up the North American Free Trade Agreement ( NAFTA ), for the period 1980-2015. Based on an empirical analysis, which includes the scrutiny of stylized facts of the monetary variables of Canada, the United States and Mexico, causality tests Granger quality and error correction models ( VEC ), it is concluded that, in parallel to the trade integration process of these countries, the monetary side of NAFTA exhibits divergences and convergences that imply an asymmetric integration of the economy Mexican with the United States and, to a lesser extent, with Canada.
\end{abstract}

Keywords: monetary convergence, inflation targeting, Canada, United States, Mexico.

\section{INTRODUCCIÓN}

The NAFTA sets the trade and financial integration between Canada, the United States and Mexico in a scheme in which each economy has preserved its pia currency and operates with a similar monetary policy framework, that of inflation (MI). Given the high degree of commercial unification between the three countries (co-total trade of US \$ 2.8 billion a day) it is appropriate to question whether this has

fostered a process of monetary convergence (or divergence) between the three economies, that facilitates or hinders commercial exchange, is insufficient I discussed you so far. (Early, 2002; Lederman, Maloney and Serven, 2005; Kammel, 2009; Blecker and Seccareccia, 2008; Puchet and Punzo, 2001).

Canada adopted an IM monetary policy framework in 1991, Mexico formally did so in 2001 and the United States Fed (Federal Reserve) did so used implicitly, flexibly and pragmatically in the years of the so-called Great Moderation (1982-2007), until, due to the influence of the effects of the crisis of 2007, as of December 2008 it began to operate with an unconventional policy focused on quantitative easing in order to stimulate the 
economic growth (Bernanke, 2015a). In all three countries, the main instrument MI's monetary policy ment is the interest rate. The objective of this work is to explore the degree of convergence of the policy

monetary policy of the NAFTA countries. The hypothesis is that it has a formal convergence occurred in the institutional context of modern politics net (autonomy of central banks, adoption of the MI scheme as

monetary policy scheme and establishment of an exchange rate scheme flexible bio) and a real divergence in the evolution of the monetary variables fundamentals (interest rate, exchange rate, money supply and demand) of the three economies that make up the Treaty. The composition of the article is as follows: in addition to this introduction, presents a succinct review of the literature on MI and on integration

monetary policy among the study countries, to later analyze some Relevant figures of the monetary policy of Canada, the United States and Mexico during the study period, 1980-2017. Finally, an ecoof the monetary asymmetries discussed above as stylized facts and the conclusion of the study is raised.

\section{DESCRIPCIÓN DEL MÉTODO}

The three study countries converge in the adoption of a policy framework

based on the MI model, whose primary objective is the stability of prices (Bernanke and Mishkin, 1997; Taylor, 1993; Clarida, Gali and Gertler, 1999; Torres, 2003; Ball and Sheridan, 2004). The MI model, according to Perrotini (2007), can be expressed with the following basic equations that are interrelated

They work to achieve the proposed objective:

$$
\begin{aligned}
& \text { and } t=Y 0-a r+\varepsilon \\
& \pi t=\pi t-1+\beta(y t-y T)+\varepsilon 2 \\
& r t=r^{*}+\emptyset \pi \pi r+\emptyset y y r
\end{aligned}
$$

Corresponding to the aggregate demand ( IS ) for the first equation, the Phillips curve for the second and the Taylor rule represented in the third equation, where: $r$ is the real interest rate, $Y 0$ is autonomous aggregate demand ma, and $t$ is the level of income observed in period $t$, and $T$ consists of the level of target income, $\pi t$ is the observed inflation, $\pi t-l$ is the observed inflation of a previous time 
period, $y r$ represents the output gap $(y t-y T), \pi r$ is the inflation gap $(\pi t-\pi T), \pi T$ is the desired inflation, $r *$ is the natural rate of

$O f$ interest, $\varepsilon 1$ and $\varepsilon 2$ represent random shocks. The potential product consists of the maximum productive capacity of the economy; the output gap measures the intensity of inflationary pressure and links the real economy to inflation. Its increase raises the prices of due to demand pressure, inducing the monetary authority to adopt higher interest rates that stabilize inflation. In an open economy there is a direct link between the interest rate real $(r t)$ and the exchange rate $(e t)$, expressed as follows:

$$
e t=r t+\varepsilon 3
$$

If the relationship between the exchange rate and the real interest rate is unitary, the former obeys the interest rate parity condition, which represents a equilibrium state in which the expected profit, expressed in national currency, nal, it is the same for assets in national currency and those denominated in foreign currency.

foreign, provided there is no arbitration. The experience of several countries with the MI model has been analyzed by diverses authors (McCallum, 1996; Bernanke, et al. , 1999; Cecchetti and Ehrmann,

2002; Neumann and von Hagen, 2002; among others). The use and application of rules monetary policies in Canada, the United States, and Mexico present specific derived from the respective structural characteristics (Torres, 2003; Philippe, Corbett and Perrier, 2006; Nakata and Schmidtz, 2016 Below we present three rules proposed as an approximation to the monetary policy rule used by each central bank, which shows that the adoption of MI has its own characteristics in each country.Philippe et al. (2006) propose a monetary policy rule for Canada characterized by minimizing a loss function that reflects preferences of the monetary authority in the face of fluctuations in inflation, output and interest rate, a rule that is represented like this:

$$
\begin{gathered}
R t=\theta R R t-1+(1-\theta R) R *+(1-\theta R)[\theta \pi(\pi a \\
t+h-\pi^{*} \\
t)+\theta \text { and YGAP } t]
\end{gathered}
$$

Where $R$ is the interest rate, $R *$ is the natural interest rate, $\pi *$

$t$ is the goal of in-

flation, $\pi a$ 
$t+h$ is the quarterly inflation rate (annualized), $R t-1$ is the interest rate of the previous period, $\theta R$ is the coefficient of the lagged interest rate, the rise of $h$ is the feedback horizon, $\theta \pi$ is the long-term response of the interest rate to movements in inflation, $\theta$ and is the long-term response of the rate of interest to changes in the output gap, and YGAP $t$ is the output gap. Equation (5) is a proposed rule for the quarterly inflation rate,

based on forecasts with a two-quarter retro-effects horizon, a high inflation coefficient (20.0), a much smaller coefficient in the output gap (0.35) and a relatively large coefficient of the rate of

lagged interest (0.95). The optimal parameterization is calculated using stochastic simulations

that estimate volatility, the persistence of inflation, the output gap and interest rates. A relevant assumption of the model is that agents have perfect knowledge of the model and the disturbances that affect the economy

nomía (Philippe et al. , 2006). Before the financial crisis of 2007-2009, in the United States the Fed operated pragmatically sticking to some kind of Taylor rule during stages of financial tranquility (Woodford, 2003) and drastically decreasing the rate discount interest and / or federal funds and increasing credit

banks in times of financial turbulence 4 (Bernanke, 2012). Is by This means that the Fed is said to have practiced an opportunistic disinflation policy (Orphanides et al. , 1997). The achievement of the monetary policies applied in The United States is based on obtaining low and stable inflation levels (Goodfriend, 2003). Obtaining bilateral correlation coefficients of the variables of monetary policy denotes a significant increase in the correspondence in its behavior in the post- NAFTA phase . The test of Granger causality, applied to both the objective and the policy instrument monetary policy between countries, denotes the hegemony of the United States over Mexico and to a lesser extent on Canada, a corollary than when contrasted with the analysis

VEC is insufficient, since the short- and long-term dynamics between objectives Tives and instruments show a stronger reciprocity between the variables. The existence of cointegration vectors confirms a relationship of length time between interest rates and price levels in the three countries. The ICT is more sensitive to TIEU than to TIM, while TIM is highly perceptual of the changes in TIEU and TIC . Finally, the TIEU is sensitive to both rates, but to a much greater extent in the face of ICT. Regarding the long-term correspondence between price levels, Canadian inflation is rigid in the face of movements in the MI and less so in the face of variations in UIS ; the IM is highly sensitive to variations in prices United States and Canada, and United States prices are affected by the deviations in Canadian prices, and they are sticky relative to changes in IM .In the short term, both interest rates and price levels will adjust for their own lags, added to those of their partners, being of greater influence the United States, followed by Canada. The contribution to the commitmention of the hypothesis raised in 
this work in this last section, based on of econometric scrutiny, allows to evidence the existence of a link desithe same among the monetary policy variables of the NAFTA partners, which is

accompanied by important divergences of structural origin, which represent disadvantages for Mexico, such as its need to attract private capital financial instruments, among other conditions, in order to offer a higher prize to Zionists who decide to place capital in Mexico.

\section{CONCLUSIONS}

In this document we have explored the monetary performance of the three economies that ake NAFTA. L to trade and financial liberalization has led to a substantial integration of their real sectors. On integration

trade has not corresponded to a concomitant convergence between the monetary rules, and monetary policy priorities differ among the three economies, although in this sense there are greater coincidences between Canada and the United States The results of our analysis allow us to confirm the hypothesis planned

teed in this research, with additional nuances from the following con clusions: first, although there is formal convergence, the economies of the NAFTA they operate with the same monetary policy framework, aimed at primary mordial and instrument are a low and stable inflation rate and the interest rate, espectively. In addition, there is an institutional context that is based on a autonomous monetary authority. Second, the empirical evidence available for the period 1980-2015 reveals that there are nonformal asymmetries in the monetary modus operandi of these economies. Within each one the inflation and interest rates converge

around low levels (in the case of Mexico the interest rate falls slightly slower than inflation, and the exchange rate tends to appreciate during the process of convergence towards monetary ability). Comparatively, yes While the inflation rates of the three economies tend to converge, the inflation rate Mexico's interest persistently exceeds those of Canada and the United States. two, which limits product growth, but contributes to stability macroeconomic and attracts foreign capital. On the other hand it generates pressures in the national currency and exchange risk associated with the loans in currency foreign banks, in addition to higher funding costs for national banks. them. Likewise, the differential between inflation and interest rates favors a tendency towards misalignment between exchange rates that is expressed in the form of appreciation of the Mexican currency, which reduces competitiveness to national commercial goods. Third, the correlation coefficients, the Granger causality tests and the VEC estimates reveal a closer correlation between the variables monetary policy in the post- NAFTA phase ; bidirectional causality relationship between TIEU and TIC, and both cause TIM. A ifitself, IEU and IC jointly determine IM. P last or, dynamics short- and long-term interest 
rates and inflation levels denote a close relationship between the three countries, characterized by the presence of a

American gemony, growing Canadian autonomy, and dependence Monetary of Mexico. Therefore, it is recommended that, when prioritizing price stability and low inflation levels, policies aimed at a change are also adopted structure that allows reducing the interest rate differential with respect to the States and accelerate economic growth without incurring imbalances of balance of payments and higher inflation. 


\section{REFERENCES}

Ball, Laurence and Niamh Sheridan (2004), "Does inflation targeting matter?", In Bernanke, Ben S. and Woodford M. (eds.), The Inflation Targeting Debate, University of Chicago, Press, Chicago.

Bayoumi, Tamim and Eichengreen, Barry (1994), "Monetary and Exchange Rate Ar- rangements for Nafta ", working document, International Monetary Fund

Bernanke, Ben Shalom and Mishkin, Frederic S. (1997), "Inflation targeting: a new framework for monetary policy?", The Journal of Economic Perspectives, vol. 11, no. 2.

Bernanke, Ben Shalom, Laubach, Thomas, Mishkin, Frederic S. and Posen, Adam (1999),Inflation Targeting: Lessons from the International Experience . Princeton Uni- versity Press, Princeton, NJ.

Bernanke, Ben Shalom (2012), "Opening Remarks: Monetary Policy since the Onset of the Crisis ", Economic Policy Symposium sponsored by The Federal Reserve

Bank of Kansas City, "The Changing Policy Landscape." Jackson Hole, Wyoming, August 31st.

Bernanke, Ben Shalom (2015a), The Courage to Act: a Memoir of a Crisis and its Aftermath, WW Norton, New York.

Bernanke, Ben Shalom (2015b), "Monetary Policy in the Future" speech for "Re-thinking Macro Policy III ", International Monetary Fund, IMF, Washington, April.

Blecker, Robert and Seccareccia, Mario (2008), "Would a North American monetary union protect Canada and Mexico against the ravages of "dutch disease"? ", The Political Economy of Monetary Policy and Financial Regulation, Political Eco nomy Research Institute ( PERI ) . University of Massachusetts, Amherst, USA .

Carrasco, Carlos and Ferreriro, Jesús (2014), "Latin American inflation differentials with USA inflation: Does Inflation Targeting make a difference? ", Journal of Economic Policy Reform, vol. 17, no. 1, pp. 1332, doi: 10.1080 / 17487870.2013 .787794$.

Castellanos, G. (2000), "The effect of the short on the interest rate structure". Banco de México Research Document Series, no. 2000-1.

Cavazos Arroyo, Guillermo and Rivas-Aceves, Salvador (2009), "Relationship between the inflation and interest rates in Mexico and the United States ", Problems of Development llo, vol. 40, no. 157, pp. 111135.

Cecchetti, Stephen and Hermann, Michael (2002), "Does inflation targeting increase output volatility? An international comparison of policymakers preferences and outcomes ", in Loayza, N. and SchmidtHebbel, K. (eds.), Monetary Policy: Rules and Transmission Mechanisms, Central Bank of Chile, Chile Chriszt, Michael (2000), "Perspectives on a Potential North American Monetary Union ", Economic Review, 4th. quarter, Federal Reserve Bank of Atlanta.

Clarida, Richard, Gali, Jordi and Gertler, Mark (1999), "The science of monetary policy: a new Keynesian perspective ”, National Bureau of Economic Research, (w7147). 
Galindo, Luis Miguel and Ros, Jaime (2009), "Banco de México: monetary policy of inflation targets ", Economía UNAM , no. 3.

Garriga, Ana (2010), "Objectives, instruments and results of monetary policy México 1980-2010", working document of the Political Studies Division of the CIDE , no. 225.

Gómez Aguirre, Mario and Rodríguez, José Carlos (2016), “Analysis of the relationship of causality between the producer and consumer price index incorporates rando variables that capture the monetary transmission mechanism: The case of NAFTA member countries ",EconoQuantum, vol. 13, no. 1, pp. 73-95.

Goodfriend, Marvin (2003), "Inflation Targeting in the United States?", Working paper, no. 9981, National Bureau of Economic Research, Cambridge, Massachusetts.

Kammel, Armin J. (2009), “Could North American Monetary Integration be an Op- timum? ”, KanadaStudien 2.1, Zeitschrift für.

Lalonde, René and St.-Amant, Pierre (1995), "Optimal currency areas: the case of Mé- xi co and the United States ”, Monetaria, October-December, pp. 431-459.

Lederman, Daniel, Maloney, William F. and Serven, Luis (2005), "Lessons from NAFTA ", Latin America and the Caribbean Countries, A Summary of Research Find- ings, The World Bank, Washington $\mathrm{DC}$

McCallum, Bennett T. (1996), "Inflation Targeting in Canada, New Zealand, Sweden, the United Kingdom, and in General ", working paper, no. 5579, The National Bureau of Economic Research, Washington DC

Mishkin, Frederic S. (2000), "From monetary targets to inflation targets: lessons from countries". Bank of Mexico, Mexico, November.

Morales Castañeda, Raúl (2001), "Monetary Union of North America, a pers-pectiva ", Foreign Trade , vol. 51, no. 6 , pp. 480-494.

Nakata, Taisuke and Schmidt, Sebastian (2016), "The Risk-Adjusted Monetary Policy Rule ". Finance and Economics Discussion Series, Divisions of Research \& Sta-Statistics and Monetary Affairs Federal Reserve Board, Washington, DC Neumann, Manfred, and Jürgen Von Hagen. (2002), "Does Inflation Targeting Matter?," Federal Reserve Bank of St. Louis Review, vol. 84, no. Four.

Orphanides, Athanasios, Small, David, Wieland, Volker and Wilcox, David (1997), "A quantitative exploration of the opportunistic approach to disinflation ", Finance and Economics Discussion Series , vol. 97, no. June 36, Board of Governorsof the Federal Reserve System.

Perrotini Hernández, Ignacio (2007), "The new monetary paradigm", Economy UNAM , vol. 4, no. 11, pp. 64-82.

Philippe, Jean, Corbett, Amy and Perrier, Patrick (2006), “An Optimized Monetary Policy Rule for To TEM ", Bank of Canada Working Paper, no. 41, November.

Puchet Anyul, Martín y Punzo, Lionello F. (2001), Mexico beyond NAFTA, Routledge, 
United Kingdom.

Taylor, John B. (1993), "Discretion versus policy rules in practice", Carnegie-Roches-ter Conference Series on Public Policy, no. 39, December.

Early, Arroyo Heliodoro (2002), "Latin America's integration processes in the light of the EU's experience with EMU ", European Economy, European Commission, Directorate-General for Economic and Financial Affairs, Economic Papers, Belgium.

Torres, Alberto (2003), "Monetary policy rules as nominal anchor: evidencia of the Mexican economy", Central Bank award“ Rodrigo Gómez 2002 ”.

Center for Latin American Monetary Studies, Mexico.

Woodford, Michael (2003), Interest and prices: Foundations of a theory of mone- tary policy, Princeton University Press, Princeton 